\title{
New observations from the intestinal fauna of Kerodon rupestris (Wied, 1820) (Rodentia, Cavidae), Brazil: a checklist spanning $\mathbf{3 0 , 0 0 0}$ years of parasitism
}

\author{
M. V. Souza $a^{a, b}$ (D), S. A. M. Chaves ${ }^{b}$ (D) and A. M. Iñiguez * (D) \\ ${ }^{a}$ Instituto Oswaldo Cruz, Fundação Oswaldo Cruz-Fiocruz, Laboratório de Tripanosomatídeos - LABTRIP, Rio de Janeiro, \\ RJ., Brasil

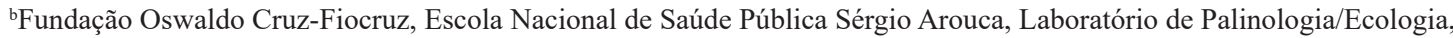 \\ Rio de Janeiro, RJ, Brasil \\ *e-mail: alenainiguez@gmail.com; alena@ioc.fiocruz.br
}

Received: 10 Jan. 2020 - Accepted: 22 Apr. 2020 - Distributed: November 30, 2021

(With 1 figure)

\begin{abstract}
This checklist of parasites of Kerodon rupestris, an endemic rodent from the Brazilian semiarid region, revealed records of 25 enteroparasite taxa comprising Cestoda (Anoplocephalidae), Trematoda, Acanthocephala and Nematoda (Ancylostomidae, Ascarididae, Heterakidae, Oxyuridae, Pharyngodonidae, Trichuridae, Capillariidae, Trichostrongylidae, and Strongyloididae), and two taxa of coccidian. Paleoparasitological and parasitological studies published until 2019 were assessed in the present study and locality information, site of infection, sample dating, and host data were summarized from each reference. Analyses of recent feces and coprolites revealed the highest species richness in the Piauí State. The chronological data corroborated that Trichuris spp. and oxyurids are part of the parasitic fauna of $K$. rupestris. This represents the first checklist of intestinal parasites from $K$. rupestris.
\end{abstract}

Keywords: Kerodon rupestris, helminths, biodiversity, rodent, Northeast Brazil.

\section{Novas observações da fauna intestinal de Kerodon rupestris (Wied, 1820) (Rodentia, Cavidae), Brasil: uma lista de verificação que abrange 30.000 anos de parasitismo}

\begin{abstract}
Resumo
Este levantamento de parasitos intestinais de Kerodon rupestris, um roedor endêmico da região semiárida brasileira, revelou registros de 25 táxons de enteroparasitos compreendendo Cestoda (Anoplocephalidae), Trematoda, Acanthocephala e Nematoda (Ancylostomidae, Ascarididae, Heterakidae, Oxyuridae, Pharyngodonidae, Trichuridae, Capillariidae, Trichostrongylidae, and Strongyloididae), e dois táxons de coccídios. Os estudos paleoparasitológicos e parasitológicos publicados até 2019 foram avaliados no presente trabalho e as informações de localização, local da infecção, datação da amostra e dados do hospedeiro, foram resumidas a partir de cada referência. Análises de fezes recentes e coprólitos revelaram a maior riqueza de espécies no estado do Piauí. Os dados cronológicos corroboram que Trichuris spp. e oxiurídeos fazem parte da fauna parasitária de K. rupestris. Essa é a primeira lista de verificação de parasitos intestinais de $K$. rupestris.
\end{abstract}

Palavras-chave: Kerodon rupestris, helmintos, biodiversidade, roedor, Nordeste do Brasil.

\section{Introduction}

Infections caused by parasites have an important role in conservation biology, for management decisions and issues related to the biology of the host population (Hudson, 2005; Thompson et al., 2010). For many vertebrate species there is a deficiency in the knowledge of their parasite fauna, thus important data area lacking concerning components of biodiversity (Poulin and Morand, 2004). Rodents account for approximately $44 \%$ of extant mammal species (see Wolf and Sherman, 2007), and serve as reservoirs for many zoonotic parasites. There are few parasite inventories from wild rodents in Brazil, and the Brazilian Northeast is especially deficient for these studies.

The genus Kerodon Cuvier, 1825 belongs to Caviidae and includes two endemic species from Brazil: K. rupestris (Wied-Neuwied, 1820) and K. acrobata Moojen, Locks and Langguth, 1997 (Oliveira and Bonvicino, 2011). These species exhibit larger corporeal size than other species in the Caviinae. Both K. rupestris and K. acrobata 
have inhabited the semi-arid region of Brazil since the Pleistocene. These rodents are also reported in small zones of the humid region in the Northeast, and northern regions of Minas Gerais State, Southeast (Moojen, 1952; Alho, 1982; Almeida et al., 2008). Both species' habitats are confined to rocky outcrops and walls of mountains where they shelter in cracks (Oliveira and Bonvicino, 2011; Lacher Junior, 2016). Historically, these rodent species suffer from hunting pressure, as they are culturally used as an alternative source of animal protein by population in the interior of northeastern Brazil (Almeida et al., 2008; Lacher Junior, 2016). They are easily hunted and highly sought after due to their large size and the quality of the meat, respectively (Alves et al., 2009; Oliveira and Bonvicino, 2011). Kerodon rupestris is considered a species of least concern because it has a sizable population and occurs in protected areas according to the List of Species Threatened by the IUCN (Catzeflis et al., 2016; Lacher Junior, 2016). Kerodon rupestris serve as a host for blood feeding triatomines, Chagas disease vectors, in the Northwest Brazil, Caatinga biome, thus, it plays an important role in Trypanosoma cruzi transmission (Bezerra et al., 2014; Almeida et al., 2016).

Parasitological studies in $K$. rupestris have been performed that analyze feces, coprolites and enteric helminths have been reported from necropsies in several regions and archaeological sites in the Northeast of Brazil (i. e. Rodrigues et al., 1985; Araújo et al., 1989; Almeida et al., 2008; Lima et al., 2017). The main objective of this study is to compile and summarize information about enteroparasites reported in K. rupestris a Brazilian endemic rodent.

\section{Material and Methods}

\subsection{Review of the literature}

The systematic review through September 2019 of the enteroparasites helminth species (Nematoda, Platyhelminthes, Acanthocephala) and the Apicomplexa reported from $K$. rupestris was conducted based on information obtained online electronic databases. The following databases were used: BioOne Complete, PubMed, Scopus, Scielo, Google Scholar, Web of Science and BioOne. For electronic search the following words were utilized: "Kerodon", "Caviidae", "faeces", "stool", "feces", "coprolites", "helminths", "protozoa", "coccidian", "parasitology", "paleoparasitology", "archaeology", "necropsy", "Nematoda", "Trematoda", "Cestoda", "Acanthocephala", "Apicomplexa", "parasite", "ancient parasites", "semiarid", "Northeast Brazil". The published data included journal articles and doctoral theses referring to the analysis of feces, coprolites and necropsied free-living and captive animals. Logical operators "AND" and "OR" were used to combine descriptors and track publications, as well as symbols "\$" and "*”" to cut off keywords in order to search all derivations. All of the studies published were included. Abstracts and presentations at conferences were not included.
The following references were used in the list for classification and systematic arrangements: Levine (1988) and the current literature for Apicomplexa (i. e. Morrison 2009); Khalil et al. (1994) for Cestoda; Vicente et al. (1997) for Nematoda; and Amin (2013) for Acanthocephala. In addition, the checklist includes some helminth species recorded only to the order or filo level (undetermined species). The names of the species follow those provided in the most recent taxonomic literature.

The species of helminths and coccidian are presented in alphabetical order, followed by information on the locality of collection, site of infection and reference. The checklist includes helminths recorded only at the genus level (undetermined species).

\section{Results}

Reports of parasites of $K$. rupestris consisted of 25 enteroparasite taxa identified based on morphometrics of eggs, oocysts and cyst as well as from whole parasite animals. Enteroparasites including Nematoda $(\mathrm{n}=20)$, Cestoda $(\mathrm{n}=1)$, Trematoda $(\mathrm{n}=1)$, Acanthocephala $(\mathrm{n}=1)$ and coccidians $(n=2)$. A total of 6 partially identified species of helminths studies was also included here. Nine and 20 taxa were found in coprolites and recent fecal samples, respectively (Figure 1). Nineteen records were found in the literature that reported on fecal parasites; $6(31.6 \%)$ were paleoparasitological analyses and $13(68.4 \%)$ used recent feces of $K$. rupestris. The list of species and genera reported follows in this section and further information on the studies is summarized in Table 1.

The coccidians, cestodes, and trematodes did not appear in past periods in K. rupestris. Trichuris spp. (11 reports), Strongyloides spp. (7 reports), and P. uncinata (5 reports), are the enteroparasites that infected the host with the highest prevalences of $58 \%, 37 \%$ and $26 \%$, respectively. Strongyloides ferreirai was described in K. rupestris and found in 8,000-year-old samples until the present. Paraspidodera uncinata appears in three studies with prevalence that reach $31 \%$. Lagochilascaris sp. was identified for the first time after 30 years of studies in the region, with $K$. rupestris acting as an intermediate host.

\section{List of species of helminths and coccidian in Kerodon rupestris}

Apicomplexa Levine, 1970 (=Sporozoa Leuckart, 1879) Coccidia Leuckart, 1879

Site of infection: small intestine

Locality: Serra da Capivara National Park, State of Piauí Reference: Vieira de Souza et al., 2019

Eucoccidiorida Léger \& Duboscq, 1910

Eimeriidae Minchin, 1903

Eimeria Schneider, 1875

Eimeria sp.

Site of infection: small intestine

Locality: Serra das Confusões National Park, State of

Piauí; Fernando de Noronha, State of Pernambuco

Reference: Sianto et al., 2006; Lima et al. 2017

Platyhelminthes Gegenbaur 1859 


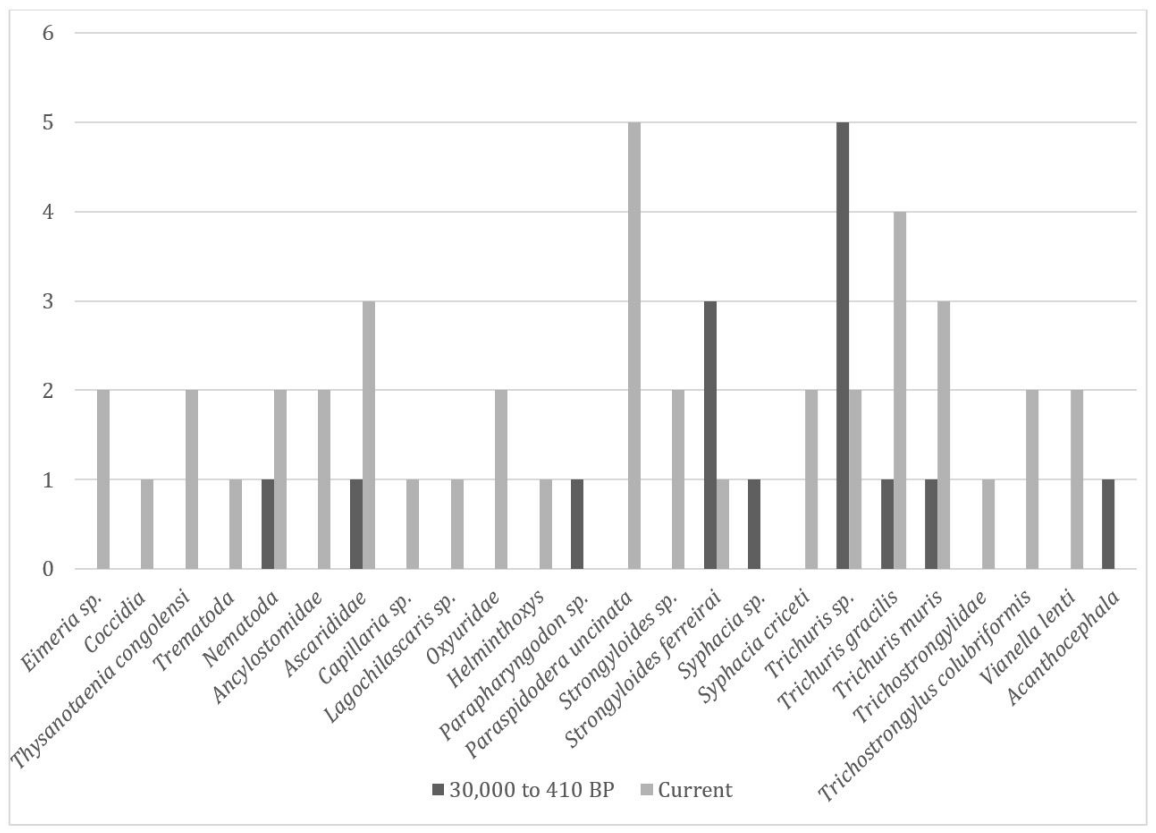

Figure 1. Number of studies by endoparasites reported on Kerodon rupestris parasitological and paleoparasitological studies.

Table 1: Endoparasites of Kerodon rupestris reported over 80 years of parasitological and paleoparasitological studies.

\begin{tabular}{|c|c|c|c|c|c|c|c|c|}
\hline Taxon & Dating & Location $^{A}$ & $\begin{array}{c}\mathrm{N} \\
\text { pos/ } \\
\text { total }\end{array}$ & $\begin{array}{c}\text { Prevalence } \\
(\%)\end{array}$ & $\begin{array}{c}\text { N eggs/ } \\
\text { cyst }\end{array}$ & $\begin{array}{c}\text { Eggs } \\
\text { measurements } \\
(\mu \mathrm{m})\end{array}$ & Material & References \\
\hline \multicolumn{9}{|l|}{ Eimeriidae } \\
\hline \multirow[t]{2}{*}{ Eimeria sp. } & current & PI, Brazil & NA & NA & NA & $28 \times 22$ & feces & $\begin{array}{l}\text { Sianto et al. } \\
\text { (2006) }\end{array}$ \\
\hline & current & $\begin{array}{l}\text { PE, } \\
\text { Brazil }\end{array}$ & $4 / 5$ & $80 \%$ & NA & NA & feces & $\begin{array}{l}\text { Lima et al. } \\
\text { (2017) }\end{array}$ \\
\hline Coccidia & current & PI, Brazil & $1 / 10$ & $10 \%$ & 1 & $38.33 \times 35.25$ & feces & $\begin{array}{l}\text { Vieira de } \\
\text { Souza et al. } \\
\text { (2019) }\end{array}$ \\
\hline \multicolumn{9}{|l|}{ Cestoda } \\
\hline $\begin{array}{l}\text { Thysanotaenia } \\
\text { congolensi }\end{array}$ & current & $\begin{array}{l}\mathrm{RN}, \\
\text { Brazil }\end{array}$ & NA & $22 \%$ & NA & $48 \times 48$ & necropsy & $\begin{array}{c}\text { Almeida (2004); } \\
\text { Almeida et al. } \\
\text { (2008) }\end{array}$ \\
\hline Trematoda & current & PI, Brazil & $2 / 231$ & $1 \%$ & 2 & $67-45 \times 37-17$ & feces & $\begin{array}{l}\text { Saldanha } \\
(2016)^{*}\end{array}$ \\
\hline \multirow[t]{3}{*}{ Nematoda } & current & PI, Brazil & $2 / 231$ & $1 \%$ & 6 & $47-67 \times 30-45$ & feces & $\begin{array}{l}\text { Saldanha } \\
(2016)^{*}\end{array}$ \\
\hline & current & PI, Brazil & NA & NA & NA & $55 \times 18$ & feces & $\begin{array}{l}\text { Sianto et al. } \\
(2006)^{*}\end{array}$ \\
\hline & $\begin{array}{c}8,870 \text { to } \\
2,000\end{array}$ & PI, Brazil & $2 / 42$ & $5 \%$ & 1 & $58 \times 40,9$ & coprolites & Sianto $(2009)^{*}$ \\
\hline \multirow[t]{3}{*}{ Ancylostomidae } & current & PI, Brazil & $4 / 231$ & $2 \%$ & 7 & $40-70 \times 25-45$ & feces & Saldanha (2016) \\
\hline & current & PI, Brazil & $2 / 231$ & $0,8 \%$ & 5 & $64.89 \times 40.96$ & feces & Saldanha (2016) \\
\hline & current & $\begin{array}{l}\text { PE, } \\
\text { Brazil }\end{array}$ & $3 / 5$ & $60 \%$ & NA & NA & feces & $\begin{array}{l}\text { Lima et al. } \\
\text { (2017) }\end{array}$ \\
\hline Ascarididae & current & $\begin{array}{l}\mathrm{RN}, \\
\text { Brazil }\end{array}$ & NA & NA & NA & NA & feces & $\begin{array}{c}\text { Pinheiro et al. } \\
\text { (1989) }\end{array}$ \\
\hline
\end{tabular}

Measurements are in $\mu \mathrm{m}$. Dating are in BP (Before Present). $a$ : States/Country. $b$ : larvae finding, no eggs were found. PI: Piauí; RN: Rio Grande do Norte; PE: Pernambuco; SP: São Paulo; MG: Minas Gerais. NA: Not available. N pos/total: number of positive samples/total of samples. N eggs: number of parasite eggs. *undetermined species. 
Table 1: Continued...

\begin{tabular}{|c|c|c|c|c|c|c|c|c|}
\hline Taxon & Dating & Location $^{A}$ & $\begin{array}{c}\mathrm{N} \\
\text { pos/ } \\
\text { total }\end{array}$ & $\begin{array}{c}\text { Prevalence } \\
(\%)\end{array}$ & $\begin{array}{c}\text { N eggs/ } \\
\text { cyst }\end{array}$ & $\begin{array}{c}\text { Eggs } \\
\text { measurements } \\
(\mu \mathrm{m})\end{array}$ & Material & References \\
\hline & current & PI, Brazil & NA & NA & NA & $69 \times 39$ & feces & $\begin{array}{l}\text { Sianto et al. } \\
(2006)\end{array}$ \\
\hline & $\begin{array}{c}2,000 \text { to } \\
3,000\end{array}$ & PI, Brazil & $1 / 42$ & $2 \%$ & 0 & NA & coprolites & Sianto (2009) \\
\hline & current & PI, Brazil & $1 / 231$ & $1 \%$ & 1 & $50.0 \times 32.5$ & feces & Saldanha (2016) \\
\hline Capillaria sp. & current & $\begin{array}{l}\text { PE, } \\
\text { Brazil }\end{array}$ & $1 / 5$ & $20 \%$ & NA & NA & feces & Lima et al. 2017 \\
\hline Helminthoxys sp. & current & PI, Brazil & $1 / 10$ & $10 \%$ & 5 & $\begin{array}{c}99.85-87.50 \times \\
52.50-40.00\end{array}$ & feces & $\begin{array}{l}\text { Vieira de } \\
\text { Souza et al. } \\
(2019)\end{array}$ \\
\hline $\begin{array}{l}\text { Lagochilascaris } \\
\text { sp. }\end{array}$ & current & PI, Brazil & $3 / 231$ & $1 \%$ & 22 & $30-52 \times 31-48$ & feces & Saldanha (2016) \\
\hline \multirow[t]{4}{*}{ Oxyuridae } & NA & PI, Brazil & $1 / 42$ & $2 \%$ & 2 & $\begin{array}{l}76.5 \times 36.6 \\
93.2 \times 39.9\end{array}$ & coprolites & Sianto (2009) \\
\hline & current & PI, Brazil & $2 / 231$ & $0,80 \%$ & 2 & $72-80 \times 38-45$ & feces & Saldanha (2016) \\
\hline & current & PI, Brazil & $10 / 231$ & $4 \%$ & 31 & $91-102$ x 38-42 & feces & Saldanha (2016) \\
\hline & current & PI, Brazil & $3 / 231$ & $3 \%$ & 2 & $77-90 \times 40-50$ & feces & Saldanha (2016) \\
\hline $\begin{array}{c}\text { Parapharyngodon } \\
\text { sp. }\end{array}$ & $8,870 \pm 60$ & PI, Brazil & $7 / 42$ & $17 \%$ & 5 & $\begin{array}{c}75.9-80.7 \mathrm{x} \\
47.0-53.3\end{array}$ & coprolites & Sianto (2009) \\
\hline \multirow{4}{*}{$\begin{array}{c}\text { Paraspidodera } \\
\text { uncinata }\end{array}$} & current & Bolivia & NA & NA & NA & NA & cecum & Gardner (1991) \\
\hline & current & $\begin{array}{l}\text { MG, } \\
\text { Brazil }\end{array}$ & NA & NA & NA & NA & necropsy & $\begin{array}{c}\text { Lent and Freitas } \\
\text { (1939) }\end{array}$ \\
\hline & current & PI, Brazil & $1 / 231$ & $0,4 \%$ & 1 & $46.72 \times 35.99$ & feces & Saldanha (2016) \\
\hline & current & $\begin{array}{l}\mathrm{RN}, \\
\text { Brazil }\end{array}$ & NA & $33 \%$ & NA & $26-28 \times 42-45$ & necropsy & $\begin{array}{l}\text { Almeida (2004); } \\
\text { Almeida et al. } \\
\text { (2008) }\end{array}$ \\
\hline \multirow[t]{2}{*}{ Strongyloides sp. } & current & PI, Brazil & NA & NA & NA & NA & feces & $\begin{array}{l}\text { Pinheiro et al. } \\
\text { (1989) }\end{array}$ \\
\hline & current & PI, Brazil & $1 / 231$ & $0,4 \%$ & 1 & $56.69 \times 29.13$ & feces & Saldanha (2016) \\
\hline \multirow[t]{4}{*}{$\begin{array}{l}\text { Strongyloides } \\
\text { ferreirai }\end{array}$} & $\begin{array}{c}8,000 \text { to } \\
2,000\end{array}$ & PI, Brazil & NA & NA & NA & NA & coprolites & $\begin{array}{c}\text { Araújo et al. } \\
\text { (1989) }\end{array}$ \\
\hline & $\begin{array}{c}7,230 \text { to } \\
2,090\end{array}$ & PI, Brazil & NA & NA & $\mathrm{NA} / 0^{B}$ & NA/larvae & coprolites & Sianto (2009) \\
\hline & 30,000 & PI, Brazil & NA & NA & $0^{B}$ & larvae & coprolites & $\begin{array}{l}\text { Ferreira et al. } \\
\qquad(1991)\end{array}$ \\
\hline & current & PI, Brazil & NA & NA & NA & $60 \times 35$ & necropsy & $\begin{array}{l}\text { Rodrigues et al. } \\
\qquad(1985)\end{array}$ \\
\hline Strongyloides ratti & current & $\begin{array}{l}\text { PE, } \\
\text { Brazil }\end{array}$ & $3 / 5$ & $60 \%$ & NA & NA & feces & $\begin{array}{l}\text { Lima et al. } \\
\text { (2017) }\end{array}$ \\
\hline Syphacia sp. & 5,300 & PI, Brazil & $3 / 93$ & $3 \%$ & 1 & $101 \times 35.7$ & coprolites & $\begin{array}{c}\text { Vieira de } \\
\text { Souza et al. } \\
(2012)\end{array}$ \\
\hline \multirow[t]{2}{*}{ Syphacia criceti } & current & SP, Brazil & NA & NA & NA & $90-98 \times 34-36$ & necropsy & $\begin{array}{c}\text { Vaz and Pereira } \\
\text { (1934) }\end{array}$ \\
\hline & current & $\begin{array}{l}\text { PE, } \\
\text { Brazil }\end{array}$ & NA & NA & NA & $83-87$ x 27-34 & necropsy & Quentin (1971) \\
\hline Trichuris sp. & 30,000 & PI, Brazil & NA & NA & 20 & $60-65 \times 30-33$ & coprolites & $\begin{array}{l}\text { Ferreira et al. } \\
\qquad(1991)\end{array}$ \\
\hline
\end{tabular}

Measurements are in $\mu \mathrm{m}$. Dating are in BP (Before Present). $a$ : States/Country. $b$ : larvae finding, no eggs were found. PI: Piauí; RN: Rio Grande do Norte; PE: Pernambuco; SP: São Paulo; MG: Minas Gerais. NA: Not available. N pos/total: number of positive samples/total of samples. N eggs: number of parasite eggs. *undetermined species. 
Table 1: Continued...

\begin{tabular}{|c|c|c|c|c|c|c|c|c|}
\hline Taxon & Dating & Location $^{A}$ & $\begin{array}{c}\mathrm{N} \\
\text { pos/ } \\
\text { total }\end{array}$ & $\begin{array}{l}\text { Prevalence } \\
\text { (\%) }\end{array}$ & $\begin{array}{l}\text { N eggs/ } \\
\text { cyst }\end{array}$ & $\begin{array}{c}\text { Eggs } \\
\text { measurements } \\
(\mu \mathrm{m}) \\
\end{array}$ & Material & References \\
\hline & $\begin{array}{c}10,050 \text { to } \\
410\end{array}$ & PI, Brazil & $16 / 42$ & $38 \%$ & 21 & $\begin{array}{l}48.5-66.6 \mathrm{x} \\
27.2-37.4\end{array}$ & coprolites & Sianto (2009) \\
\hline & 9,000 & PI, Brazil & $1 / 93$ & $1 \%$ & 20 & $59-66 \times 33$ & coprolites & $\begin{array}{l}\text { Araújo et al. } \\
\text { (1993) }\end{array}$ \\
\hline & $\begin{array}{c}8,000 \text { to } \\
2,000\end{array}$ & PI, Brazil & NA & NA & NA & $61.96 \times 31.65$ & coprolites & $\begin{array}{l}\text { Araújo et al. } \\
\text { (1989) }\end{array}$ \\
\hline & NA & $\begin{array}{l}\text { PE, } \\
\text { Brazil }\end{array}$ & $1 / 15$ & $7 \%$ & 3 & $66.60 \times 33.30$ & coprolites & Duarte (1994) \\
\hline & current & PI, Brazil & NA & NA & NA & $62-70 \times 32-37$ & feces & $\begin{array}{l}\text { Sianto et al. } \\
\text { (2006) }\end{array}$ \\
\hline & current & PI, Brazil & $18 / 231$ & $8 \%$ & 28 & $\begin{array}{c}57-67 \times \text { e } \\
30-35\end{array}$ & feces & Saldanha (2016) \\
\hline \multirow[t]{4}{*}{ Trichuris gracilis } & $\begin{array}{c}3,430 \pm \\
40\end{array}$ & PI, Brazil & $6 / 9$ & $67 \%$ & 17 & $\begin{array}{c}58.42-64.50 \mathrm{x} \\
30.16-38.46\end{array}$ & coprolites & $\begin{array}{c}\text { Vieira de Souza } \\
\text { (2013) }\end{array}$ \\
\hline & current & $\begin{array}{l}\mathrm{RN}, \\
\text { Brazil }\end{array}$ & NA & $22 \%$ & NA & $60-66$ x 30-34 & necropsy & $\begin{array}{c}\text { Almeida (2004); } \\
\text { Almeida et al. } \\
\text { (2008) }\end{array}$ \\
\hline & current & PI, Brazil & $10 / 231$ & $4 \%$ & 30 & $55-69 \times 32-35$ & feces & Saldanha (2016) \\
\hline & current & PI, Brazil & $5 / 10$ & $50 \%$ & 29 & $\begin{array}{c}68.05-59.49 x \\
35.00-31.61\end{array}$ & feces & $\begin{array}{c}\text { Vieira de } \\
\text { Souza et al. } \\
(2019)\end{array}$ \\
\hline \multirow[t]{3}{*}{ Trichuris muris } & $\begin{array}{c}3,430 \pm \\
40\end{array}$ & PI, Brazil & $6 / 9$ & $67 \%$ & 8 & $\begin{array}{c}57.50-65.00 x \\
34.03-37.84\end{array}$ & coprolites & $\begin{array}{c}\text { Vieira de Souza } \\
\quad(2013)\end{array}$ \\
\hline & current & $\begin{array}{c}\mathrm{RN}, \\
\text { Brazil }\end{array}$ & NA & $22 \%$ & NA & $63-69 \times 36-40$ & necropsy & $\begin{array}{c}\text { Almeida (2004); } \\
\text { Almeida et al. } \\
\text { (2008) }\end{array}$ \\
\hline & current & PI, Brazil & $3 / 231$ & $1 \%$ & 20 & $58-75$ x 33-40 & feces & Saldanha (2016) \\
\hline Trichostrongylidae & current & PI, Brazil & $29 / 231$ & $13 \%$ & 130 & $44-67$ x 15-22 & feces & Saldanha (2016) \\
\hline $\begin{array}{l}\text { Trichostrongylus } \\
\text { colubriformi }\end{array}$ & current & $\begin{array}{l}\mathrm{RN}, \\
\text { Brazil }\end{array}$ & NA & $56 \%$ & NA & NA & necropsy & $\begin{array}{c}\text { Almeida (2004); } \\
\text { Almeida et al. } \\
\text { (2008) }\end{array}$ \\
\hline Vianella lenti & current & $\begin{array}{l}\mathrm{RN}, \\
\text { Brazil }\end{array}$ & NA & $33 \%$ & NA & $40-50 \times 30$ & necropsy & $\begin{array}{c}\text { Almeida (2004); } \\
\text { Almeida et al. } \\
\text { (2008) }\end{array}$ \\
\hline Acanthocephala & 3,000 & PI, Brazil & $1 / 42$ & $2 \%$ & 1 & $86.5 \times 46.6$ & coprolites & Sianto (2009)* \\
\hline
\end{tabular}

Measurements are in $\mu \mathrm{m}$. Dating are in BP (Before Present). $a$ : States/Country. $b$ : larvae finding, no eggs were found. PI: Piauí; RN: Rio Grande do Norte; PE: Pernambuco; SP: São Paulo; MG: Minas Gerais. NA: Not available. N pos/total: number of positive samples/total of samples. $\mathrm{N}$ eggs: number of parasite eggs. *undetermined species.

Cestoda van Beneden, 1849

Cyclophyllidea Braun, 1900

Anoplocephalidae Cholodkovsky, 1902

Thysanotaenia Beddard, 1911

Thysanotaenia congolensis Dronen, Simcik,

Scharninghausen and Pitts, 1999

Site of infection: small intestine

Locality: Mossoró, State of Rio Grande do Norte

Reference: Almeida, 2004; Almeida et al., 2008

Trematoda Rudolphi, 1808

(not identified the genus and species)

Site of infection: bile ducts, pancreatic, urinary tract

Locality: Serra das Capivara National Park, State of Piauí
Reference: Saldanha, 2016

Nematoda Rudolphi, 1808

(not identified the genus and species)

Site of infection: small intestine, large intestine and cecum

Locality: Serra das Capivara and Serra das Confusões

National Park, State of Piauí

Reference: Sianto et al., 2006; Sianto, 2009; Saldanha, 2016.

Ascaridoidea Baird, 1853

Ascarididae Baird, 1853

(not identified the genus and species)

Site of infection: large intestine, stomach

Locality: Serra das Capivara and Serra das Confusões

National Park, State of Piauí; State of Rio Grande do Norte 
Reference: Pinheiro et al., 1989; Sianto, 2009; Sianto et al., 2006; Saldanha, 2016

Lagochilascaris Leiper, 1919

Lagochilascaris sp.

Site of infection: large intestine, stomach

Locality: Serra das Capivara, State of Piauí

Reference: Saldanha, 2016

Aspidoderidae Skrjabin and Schikobalova, 1947

Paraspidodera uncinata (Rudolphi, 1819) Travassos, 1914

Site of infection: large intestine, stomach

Locality: Bolivia; States of Minas Gerais, Piauí, and

Rio Grande do Norte, Brazil

Reference: Lent and Freitas, 1939; Gardner, 1991;

Almeida, 2004; Almeida et al., 2008; Saldanha, 2016.

Oxyurida Chabaud, 1974

Oxyuroidea Cobbold

Oxyuridae Cobbold, 1864

Syphaciinae Railliet, 1916

Helminthoxys Freitas, Lent and Almeida, 1937

Site of infection: Caecum and large intestine

Locality: Serra da Capivara National Park, State of Piauí

Reference: Vieira de Souza et al., 2019

Syphacia Seurat, 1916

Syphacia criceti (Quentin, 1969)

Site of infection: Caecum and large intestine

Locality: Serra das Capivara National Park, State of

Piauí; State of Pernambuco; State of São Paulo

Reference: Vaz and Pereira, 1934; Quentin, 1971;

Vieira de Souza et al., 2012.

Pharyngodonidae Travassos 1919

Oxyurinae Hall, 1916

Parapharyngodon Chatterji, 1933

Parapharyngodon sp.

Site of infection: Caecum and large intestine

Locality: Serra das Capivara National Park, State of Piauí

Reference: Sianto, 2009

Secernentea von Linstow, 1905

Trichostrongyloidea Chitwood, 1933

Trichostrongylidae Leiper, 1909

(not identified the genus and species)

Site of infection: small intestine

Locality: Serra das Capivara National Park, State of Piauí

Reference: Saldanha, 2016

Trichostrongylus Looss 1905

Trichostrongylus colubriformis (Giles, 1892)

Site of infection: small intestine

Locality: Serra das Capivara National Park, State of Piauí

Reference: Almeida, 2004; Almeida et al., 2008.

Rhabditida Chitwood, 1933

Strongyloidea Weinland, 1858

Ancylostomatidae Looss, 1905

(not identified the genus and species)

Site of infection: large intestine, stomach

Locality: Serra das Capivara National Park, State of

Piauí; Fernando de Noronha, State of Pernambuco

Reference: Saldanha, 2016; Lima et al. 2017

Strongyloididae Chitwood and MacIntosh, 1934

Strongyloides Grassi, 1879
Strongyloides sp.

Site of infection: small intestine

Locality: State of Piauí

Reference: Pinheiro et al., 1989; Saldanha, 2016

Strongyloides ferreirai Rodrigues, Vicente and Gomes 1985

Site of infection: small intestine

Locality: Serra das Capivara National Park and surroundings, State of Piauí

Reference: Rodrigues et al., 1985; Araújo et al., 1989;

Ferreira et al., 1991; Sianto, 2009

Strongyloides ratti Sandground, 1925

Site of infection: small intestine

Locality: Fernando de Noronha, State of Pernambuco

Reference: Lima et al., 2017

Viannaiidae Durette-Desset and Chabaud, 1981

Vianella Travassos, 1918

Vianella lenti Durette-Desset, 1968

Site of infection: small intestine

Locality: Mossoró, State of Rio Grande do Norte

Reference: Almeida, 2004; Almeida et al., 2008

Trichocephalida (=Trichinellida) Spasski, 1954

Capillariidae Railliet, 1915

Capillaria Zeder, 1800

Capillaria sp.

Site of infection: uninformed

Locality: Fernando de Noronha, State of Pernambuco

Reference: Lima et al., 2017

Trichuridae Railliet, 1915

Trichuris sp. Roederer, 1761

Site of infection: small intestine

Locality: Mossoró, State of Rio Grande do Norte; Serra das Capivara National Park and surroundings, State of Piauí; State of Pernambuco

Reference: Araújo et al., 1989, 1993; Ferreira et al., 1991; Duarte, 1994; Sianto et al., 2006; Sianto, 2009; Saldanha, 2016.

Trichuris gracilis (Roederer, 1819) Hall, 1916

Site of infection: small intestine

Locality: Mossoró, State of Rio Grande do Norte; Serra da Capivara and Serra das Confusões National Park, State of Piauí; State of Pernambuco

Reference: Almeida, 2004; Almeida et al., 2008; Vieira de Souza, 2013, et al., 2019; Saldanha, 2016.

Trichuris muris (Schrank, 1788)

Site of infection: small intestine

Locality: Mossoró, State of Rio Grande do Norte; Serra da Capivara and Serra das Confusões National Park, State of Piauí; State of Pernambuco

Reference: Almeida, 2004; Almeida et al., 2008; Vieira de Souza, 2013; Saldanha, 2016

Acanthocephala Koelreuter, 1771

(not identified the genus and species)

Site of infection: small intestine

Locality: Serra das Capivara National Park, State of Piauí Reference: Sianto, 2009 


\section{Discussion}

Intestinal helminths that have a close and long association with their hosts over the time, may reflect behaviors and lifestyles of rodents as well as with the local environmental conditions, allowing a better understanding of the hostparasite relationship (Hugot et al., 1999; Ferreira, 2011). In this work, we observed a large number of intestinal taxa in K. rupestris. These studies on K. rupestris began in the 1980s, in the Serra do Capivara National Park, with the aim of comparing the results obtained by Paleoparasitology (Felice et al., 2014). Since then, the most frequently reported taxa have been the nematode Trichuris spp., followed by Oxyuridae and Ascarididae. The first study registered was conducted by Vaz and Pereira (1934) who reported the presence of Syphacia criceti (Nematoda: Oxyuridae) in a necropsied animal dead in captivity in São Paulo, Brazil. Trichuris sp. is one of the oldest helminths recorded in the New World, at 30,000 years BP (Ferreira et al., 1991).

Eimeria sp. was the only coccidia report in K. rupestris, and could be an occasional parasite, since is found in a great diversity of hosts in Brazil as Canidae, Felidae, Suidae, ruminant mammals, birds, and few rodents. However, others coccidia were reported in the region as Giardia sp., Cryptosporidium sp., and Cystoisospora sp., but in other caviids (Gressler et al., 2010). The survey presented here, spanning more than 80 years of studies, shows that the analyses have been done focusing mainly on helminth parasites and little is known about the protozoan parasites.

Trichurids are present in all vertebrate groups, but mainly in birds and mammals (Anderson, 2000; Schmidt and Roberts, 2009). They possess a stenoxenic cycle adapted to a single host or hosts phylogenetically close related. The eggs are quite resistant to environmental factors due to their thick shell and can remain viable in the soil for up to six years (Fortes, 1997). Twenty-seven species of Trichuris were described in rodents from South and North America, with only four species reported in Brazil, one in Caviidae (Yamaguti, 1963; Robles et al., 2018). The species T. gracilis and T. muris were reported in studies with ancient and modern material (Almeida et al., 2008; Vieira de Souza, 2013; Vieira de Souza et al., 2019; Saldanha, 2016). In the more recent study, Trichuris sp. eggs were found near human villages, where the small populations of $K$. rupestris remained in the border areas of the hill ranges and rocky canyons (Saldanha, 2016; Vieira de Souza et al., 2019). It is not possible to affirm that the same species is found in modern and ancient material, however, the present review shows the persistence of the Trichuris genus in this Brazilian region for at least 30,000 years, until present day. The data allow to speculated a possible adaptation of this parasite to the climate, since the genus is dependent on specific conditions of humidity and temperature to conclude its biological cycle in the soil. The suitable temperature for the development of Trichuris sp. eggs in soil varies between $25^{\circ} \mathrm{C}$ and $37.5^{\circ} \mathrm{C}$, with lower temperatures retarding or preventing the process, and higher temperatures accelerating or harming egg development (Spindler, 1929; Vejzagic et al., 2016). In periods of rain, Trichuris sp. becomes more active due to greater humidity, while in periods of less humidity, such as in the dry season, the reproduction of helminths is low, with little egg elimination. In times of drought, however, the parasite may remain in available humid places (Spindler, 1929; Vejzagic et al., 2016).

Capillaria, which belongs to the same order as Thichuris sp., is a large genus that includes species found in almost every organ and tissue of all vertebrate classes (Schmidt and Roberts, 2009). Therefore, finding eggs in $K$. rupestris feces may be an occasional case due to the rodent's coprophagy habit.

Oxyurids mainly infect mammals, but also invertebrates, amphibians and birds (Hugot, 1988). They have a high host specificity and a monoxenic cycle, with transmission and development similar in invertebrate and vertebrate hosts (Hugot, 1988; Hugot et al., 1999; Anderson, 2000). Oxyuroidea are currently grouped into three families: Oxyuridae, Pharyngodonidae and Heteroxynematidae (Skrjabin et al., 1974; Hugot, 1988; Petter and Quentin, 2009). According to the present review, the oldest oxyuriid recorded in K. rupestris was Syphacia sp., 5,300 years ago. Modern records included two studies in necropsied animals and one in feces. Syphaciinae is apparently a recent group that emerged and dispersed in the main groups of rodents, with morphological adaptations of their different hosts (Hugot, 1988). However, Oxyuridae have fragile and light eggs, deposited in the perianal region of the host, which may hamper the number of egg findings in feces. Other oxyurid reported was Parapharyngodon sp. (Pharyngodonidae), parasite of reptilians, in Serra da Capivara National Park. The finding represents an accidental parasitism event, related to the ingestion of lacertid feces (Sianto, 2009). Helminthoxys sp. was most recently recorded for the first time in K. rupetris from the same region, parasites of neotropical caviomorphas rodents that inhabit the caecum and large intestine of their hosts (Hugot and Sutton, 1989). It currently comprises nine species, with $H$. freitasi Quentin, 1969 and H. urichi (Cameron \& Reesal, 1951) Hugot, 1986 described for rodents from Brazil (Gonçalves et al., 2006; Quentin, 1969).

Eggs of nematodes belonging to the genus Paraspidodera (Gardner, 1991), which infect Caviidae, Dasyproctidae and Leporidae (Vicente et al., 1997) were also reported. In Brazil, three species of Cavia (C. fulgida, C. porcellus and C. aperea) were cited as hosts for Paraspidodera uncinata (Vicente et al., 1997). Since they are in sympatry with $K$. rupestris, it is possible to suggests that they share these parasites. Another interesting finding is Lagochilascaris cf. minor, a parasite of Public Health importance (Saldanha, 2016). However, it was not possible to confirm true parasitism due to lack of complementary information on the biological cycle of this helminth. The parasite has been identified in humans (Fortes, 1997), dogs and domestic cats (Campos et al., 1992). According to experimental studies, rodents would act as intermediate hosts of Lagochilascaris spp. (Campos et al., 1992). Other authors 
argue that rodents can be considered definitive hosts of L. minor due to the observation of an adult helminth, but without data of egg laying (Freitas et al., 2008).

Thysanotaenia congolensis is a cestode currently described for African rodents (Dronen et al., 1999), and was found in a single study in Rio Grande do Norte (Almeida et al., 2008). Thysanotaenia congolensis is a cestode currently found in African rodents of the Thynomyidae family (Dronen et al., 1999). However, there is one report in K. rupestris from Rio Grande do Norte, Brazil (Almeida et al., 2008). The authors suggested that their presence in $K$. rupestris is probably due to the common origin of these rodent families, or could be acquired by cohabitation with other caviomorphas, as already suggested for Vianella lenti, parasite of Galea spixii, also found in K. rupestris (Almeida et al. 2008).

A species of Strongyloides was described only for the host $K$. rupestris and named S. ferreirai by Rodrigues, Vicente and Gomes (1985).

In addition, it has coprophagic habits (Moojen, 1952; Alho, 1982; Chame, 2007; Almeida et al., 2008), that allow the acquisition of parasites from sympatric animals, as canids and felines. Investigations of the helminth fauna could help in the monitoring of parasite populations in the region, in the prediction of the emergence or extinction of parasites species, and in the impacts that these ecological processes may have on future of animal populations (Ogunseitan, 2005).

In conclusion, the present compilation of literature demonstrated that Trichuris spp. are still the most reported helminths parasitizing $K$. rupestris, followed by oxyurids. Consequently, they appear to be, in fact, the parasitic fauna of this rodent. Sporadic reports of other helminths and coccidia are probably related to the presence of animals that cohabit the region, or to anthropization.

This survey constitutes the first checklist of enteroparasites in K. rupestris. These data may be useful for studies on the biology of local species conservation.

\section{Acknowledgements}

\author{
CAPES (23038.000059/2015-61), FAPERJ (CNE \\ E-26/202.945/2016), CNPq (307932/2014-1 312934/2017-3 \\ and 151879/2019-2).
}

\section{References}

ALHO, C.J.R., 1982. Brazilian rodents: their habitats and habits. In: Mares MA and Genoways HH, eds. Mammalian Biology in South America. Pittsburgh: Special Publication, Pymatuning Laboratory of Ecology, University of Pittsburgh, pp. 143-166.

ALMEIDA, C.E., FAUCHER, L., LAVINA, M., COSTA, J. and HARRY, M., 2016. Molecular Individual-Based Approach on Triatoma brasiliensis: Inferences on Triatomine Foci, Trypanosoma cruzi Natural Infection Prevalence, Parasite Diversity and Feeding Sources. PLoS Neglected Tropical Diseases, vol. 10, no. 2, pp. 1-19. http://dx.doi.org/10.1371/journal.pntd.0004447. PMid:26891047.
ALMEIDA, K., 2004. Helmintos parasitos de mocós (Kerodon rupestris Niewid-Wied, 1820), de vida livre e de cativeiro, criados no semi-árido nordestino. São Paulo: Universidade Estadual Paulista, Faculdade de Ciências Agrárias e Veterinárias, 55 p. Dissertação de Mestrado em Medicina Veterinária Preventiva.

ALMEIDA, K.S., FREITAS, F.L.C., TEBALDI, J.H. and NASCIMENTO, A.A., 2008. Helmintos parasitos de Mocós (Kerodon rupestris Rodentia: Caviidae) de vida livre e de cativeiro, no semiárido nordestino brasileiro. Archives of Veterinary Science, vol. 13, no. 2, pp. 133-139. http://dx.doi.org/10.5380/ avs.v13i2.11614.

ALVES, L.I.F., SILVA, M.M.P. and VASCONCELOS, K.J., 2009. Visão de comunidades rurais em Juazeirinho/PE referente a extinção da biodiversidade da Caatinga. Revista Caatinga, vol. 22, no. 4, pp. 180-186.

AMIN, O.M., 2013. Classification of the Acanthocephala. Folia Parasitologica, vol. 60, no. 4, pp. 273-305. http://dx.doi. org/10.14411/fp.2013.031. PMid:24261131.

ANDERSON, R.C., 2000. Nematode parasites of vertebrates: their development and transmission. Wallingford, UK: CAB International, 650 p. http://dx.doi.org/10.1079/9780851994215.0000.

ARAÚJO, A., FERREIRA, L.F., CONFALONIERI, U., CHAME, M. and RIBEIRO, B.M., 1989. Strongyloides ferreirai Rodrigues, Vicente and Gomes, 1985 (Nematoda, Rhabdiasoidea) in rodent coprolites (8,000-2,000 years BP), from archaeological sites from Piauí, Brazil. Memorias do Instituto Oswaldo Cruz, vol. 84, no. 4, pp. 493-496. http://dx.doi.org/10.1590/S0074-02761989000400006. PMid:2487446.

ARAÚJO, A., RANGEL, A. and FERREIRA, L.F., 1993. Climatic change in northeastern Brazil - paleoparasitological data. Memorias do Instituto Oswaldo Cruz, vol. 88, no. 4, pp. 577-579. http:// dx.doi.org/10.1590/S0074-02761993000400014.

BEZERRA, C.M., CAVALCANTI, L.P., SOUZA, R.C., BARBOSA, S.E., XAVIER, S.C., JANSEN, A.M., RAMALHO, R.D. and DIOTAIUT, L., 2014. Domestic, peridomestic and wild hosts in the transmission of Trypanosoma cruzi in the Caatinga area colonised by Triatoma brasiliensis. Memorias do Instituto Oswaldo Cruz, vol. 109, no. 7, pp. 887-898. http://dx.doi.org/10.1590/00740276140048 . PMid:25410992.

CAMPOS, D.M.B., FREIRE-FILHA, L.G., VIEIRA, M.A., PAÇO, J.M. and MAIA, M.A., 1992. Experimental life cycle of Lagochilascaris minor Leiper, 1909. Revista do Instituto de Medicina Tropical de São Paulo, vol. 34, no. 4, pp. 277-287. http:// dx.doi.org/10.1590/S0036-46651992000400003. PMid:1342084.

CATZEFLIS, F., PATTON, J., PERCEQUILLO, A., and WEKSLER, M., 2016. Kerodon rupestris. The IUCN Red List of Threatened Species, e.T10988A22190269. IUCN.

CHAME, M., 2007. Reservatórios de água e implicações na distribuição de mamíferos cinegéticos no semiárido: contribuições à conservação do Parque Nacional Serra da Capivara, sudeste do Piaui, Brasil. Rio de Janeiro: Universidade Federal do Rio de Janeiro, Museu Nacional, 325 p. Tese de Doutorado em Ciências Biológicas.

DRONEN, N.O., SIMCIK, S.R., SCHARNINGHAUSEN, J.J. and PITTZ, R.M., 1999. Thysanotaenia congolensis n sp. (Centoda: Anplocephalidae) in the Lesser Savanna Cane Rat, Thrynomys gregorianus from Democratic Republic of Congo, Africa. The Journal of Parasitology, vol. 85, no. 1, pp. 90-92. http://dx.doi. org/10.2307/3285706. PMid:10207370. 
DUARTE, A.N., 1994. Estudo paleoparasitológico em coprólitos do sítio arqueológico da Furna do Estrago, Município do Brejo da Madre de Deus, Pernambuco-Brasil. Rio de Janeiro: Universidade Federal Rural do Rio de Janeiro, 117 p. Dissertação de Mestrado.

FELICE, D.G., GUIDON, N. and MENDES, V.R., 2014. A evolução da Paisagem no Pleistoceno Superior ao Holoceno na Região do Parque Nacional da Serra da Capivara. In: A.M. PESSIS, G. MARTIN and N. GUIDON, eds. Os Biomas e as Sociedades Humanas na Pré-História da Região do Parque Nacional da Serra da Capivara, São Paulo: A\&A, pp. 68-86.

FERREIRA, L.F., 2011. Introdução a Paleoparasitologia. In: L.F. FERREIRA, K.J. REINHARD, and A. ARAÚJO, eds. Fundamentos da Paleoparasitologia. Rio de Janeiro: Fundação Oswaldo Cruz, pp. 27-41.

FERREIRA, L.F., ARAÚJO, A., CONFALONIERI, U., CHAME, M. and GOMES, D.C., 1991. Trichuris eggs in animal coprolites dated from 30,000 years ago. The Journal of Parasitology, vol. 77, no. 3, pp. 491-493. http://dx.doi.org/10.2307/3283143. PMid:2040962.

FORTES, E., 1997. Parasitologia Veterinária. 3. ed. São Paulo: Ícone, $686 \mathrm{p}$.

FREITAS, J.G., PRUDENTE, M.F.S., SPADAFORA-FERREIRA, M., JUNQUEIRA-KPNIS, P., CÂNDIDO DE PAULA, E., TAMBOURGI, D.V., LINO-JÚNIOR, R.S. and CARVALHAES, M.S., 2008. Lagochilascaris minor: experimental infection of $\mathrm{C} 57 \mathrm{BL} / 6$ and BALB/c isogenic mice reveals the presence of adult worms. Experimental Parasitology, vol. 119, no. 3, pp. 325-331. http://dx.doi.org/10.1016/j.exppara.2008.03.009. PMid:18456261.

GARDNER, S.L., 1991. Phyletic coevolution between subterranean rodents of the genus Ctenomys (Rodentia: Hystricognathi) and nematodes of the genus Paraspidodera (Heterakoidea: Aspidoderidae) in the Neotropics: temporal and evolutionary implications. Zoological Journal of the Linnean Society, vol. 102, no. 2, pp. 169-201. http://dx.doi.org/10.1111/j.1096-3642.1991.tb00288.x.

GONÇALVES, A.Q., BÓIA, M.N., COURA, J.R. and PINTO, R.M., 2006. New records for helminths of hystricognath rodents from the middle and high Rio Negro microregion, State of Amazonas, Brazil. Revista Brasileira de Zoologia, vol. 23, no. 3, pp. 716-726. http://dx.doi.org/10.1590/S0101-81752006000300016.

GRESSLER, L.T., SILVA, A.S., SILVA, M.K., TONIN, A.A. and MONTEIRO, S.G., 2010. Gastrointestinal parasites of cavy (Cavia aperea aperea) in southern Brazil. Research in Veterinary Science, vol. 89, no. 2, pp. 206-208. http://dx.doi.org/10.1016/j. rvsc.2010.02.012. PMid:20227736.

HUDSON, P.J. 2005. Parasites, diversity and the ecosystem. In: F. THOMAS, F. RENAUD and J. GUEGAN, eds. Parasitism and Ecosystems. Oxford: Oxford University Press, pp. 1-12.

HUGOT, J.P. and SUTTON, C.A., 1989. Etude morphologique de deux oxyures appartenant au genre Helminthoxys. Bulletin du Muséum National d'Histoire Naturelle, vol. 9, no. 4, pp. 387-395.

HUGOT, J.P., 1988. Les nématodes Syphaciinae parasites de Rongeurs et de Lagomorphes. Taxonomie. Zoogéographie. Evolution. Mémoires du Muséum National d'Histoire Naturelle, Série A. Zoologie, vol. 141, pp. 1-153.

HUGOT, J.P., REINHARD, K.J., GARDNER, S.L. and MORAND, S., 1999. Human enterobiases in evolution: origin, specificity e transmission. Parasite (Paris, France), vol. 6, no. 3, pp. 201-208. http://dx.doi.org/10.1051/parasite/1999063201. PMid:10511967.
KHALIL, L.F., JONES, A. and BRAY, R.A., 1994. Keys to the cestode parasites of vertebrates. Wallingford, Oxon: Cab. International $768 \mathrm{p}$.

LACHER JUNIOR, T.E., 2016. Family Caviidae. In: WILSON, D.E., LACHER JUNIOR, T.E., \& MITTERMEIER, R.A., eds. Handbook of Mammals of the World: Lagomorphs and Rodents: Part 1. Barcelona: Lynx Editions.

LENT, H. and FREITAS, J.F.T., 1939. Some remarks on the genus Paraspidodera Travassos, 1914 (Nematoda: Subuluroidea). Volume Jubilaire Pro Proffesor S. Yoshida, Osaka, Japan, vol. 2, pp. $273-278$

LEVINE, N.D., 1988. The protozoan phylum Apicomplexa. Boca Raton, FL: CRC Press, vol. 2, 357 p.

LIMA, V.F.S., RAMOS, R.A.N., LEPOLD, R., BORGES, J.C.G., FERREIRA, C.D., RINALDI, L., CRINGOLI, G. and ALVES, L.C., 2017. Gastrointestinal parasites in feral cats and rodents from the Fernando de Noronha Archipelago, Brazil. Revista Brasileira de Parasitologia Veterinária, vol. 26, no. 4, pp. 521-524. http:// dx.doi.org/10.1590/s1984-29612017066. PMid:29160359.

MOOJEN, J., 1952. Os roedores do Brasil. Rio de Janeiro: Ministério da Educação e Saúde, Instituto Nacional do Livro, Biblioteca Científica Brasileira, Série A, II, 214 p.

MORRISON, D.A., 2009. Evolution of the Apicomplexa: where are we now? Trends in Parasitology, vol. 25, no. 8, pp. 375-382. http://dx.doi.org/10.1016/j.pt.2009.05.010. PMid:19635681.

OGUNSEITAN, O., 2005. Microbial diversity: form and function in Prokaryotes. Oxford: Blackwell Publishing, 312 p.

OLIVEIRA, J.A. and BONVICINO, C.R., 2011. Ordem Rodentia. In: N.R. REIS, A.L. PERACCHI, W.A. PEDRO and I.P. LIMA, eds. Mamíferos do Brasil, $2^{\mathrm{a}}$ ed., Londrina: N. R. Reis, pp. 358-406.

PETTER, A.J. and QUENTIN, J.C., 2009. Oxyurida. In: R.C. ANDERSON, A.G. CHABAUD and S. WILLMOTT, eds. Keys to the Nematode Parasites of Vertebrates: archival volume. Wallingford, UK: CAB International, pp. 218-247. http://dx.doi. org/10.1079/9781845935726.0218.

PINHEIRO, M.J.P., ANDRADE, S.A. and CUNHA, J.N., 1989. Preservação e exploração de animais silvestres nativos: preá, cutia e mocó. Revista Caatinga, Mossoró, vol. 6, pp. 28-49.

POULIN, R. and MORAND, S., 2004. Parasite biodiversity. Washington D.C.: Smithsonian Books, 216 p.

QUENTIN, J. C., 1971. Morphologie comparée des structures céphaliques et genitales des Oxyures du genre Syphacia. Annales de Parasitologie (Paris), vol. 46, pp. 15-60. Avaliable from: https://www.parasite-journal.org/articles/parasite/pdf/1971/01/ parasite1971461p15.pdf.

QUENTIN, J.C., 1969. Etude de nématodes Syphacia parasites de Rongeurs Cricetidae sudaméricains et de leurs corrélations biogéographiques avec certaines espèces néartiques. Bulletin du Muséum National d'Histoire Naturelle, vol. 4, pp. 909-925.

ROBLES, M.R., CUTILLAS, C. and CALLEJÓN, R., 2018. Morphological-molecular characterization and phylogenetic relationships of a new Trichuris species (Nematoda: Trichuridae) parasitic on Holochilus chacarius (Cricetidae: Sigmodontinae) from the Chaco ecoregion (Argentina). Infection, Genetics and Evolution, vol. 58, pp. 66-76. http://dx.doi.org/10.1016/j. meegid.2017.11.029. PMid:29241714.

RODRIGUES, H.O., VICENTE, J.J. and GOMES, D.C., 1985. Strongyloides ferreirai sp. n. (Nematoda, Rhabdiasoidea) parasito 
do roedor Kerodon rupestris (Wied.) no Brasil. Memorias do Instituto Oswaldo Cruz, vol. 80, no. 4, pp. 407-410. http://dx.doi. org/10.1590/S0074-02761985000400005.

SALDANHA, B.M., 2016. Diversidade de helmintos intestinais em mocós Kerodon rupestris (Wied-Neuwied, 1820) no Parque Nacional Serra da Capivara, Piauí, Brasil: uma síntese em 30 anos de informação. Rio de Janeiro: Universidade Federal Fluminense, 148 p. Dissertação de Mestrado em Microbiologia e Parasitologia.

SCHMIDT, G.D. and ROBERTS, L.S., 2009. Foundations of Parasitology. 8th ed. New York: McGraw-Hill, 701 p.

SIANTO, L., 2009. Parasitismo em populações Pré-Colombianas: helmintos de animais em coprólitos de origem humana do Parque Nacional Serra da Capivara, PI, Brasil. Rio de Janeiro: Fundação Oswaldo Cruz, Escola Nacional de Saúde Pública, 189 p. Tese de Doutorado em Saúde Pública.

SIANTO, L., CHAME, M., FERREIRA, L.F. and ARAUJO, A.J.G., 2006. Parasites and Climate changes. In: 10th Conference of International Council for Archeozoology, 2006, Mexico. Mexico: Instituto National de Antropologia e Historia, vol. 1, pp. 164-165.

SKRJABIN, K.I., SHIKHOBALOBA, N.P. and LAGADOVSKAYA, E.A., 1974. Oxyurata of Animals and Man, part. two, Essential and Nematodology, ad, by Skrjabin KK. vol. 10. Translated from Russian, Israel Program for Scientific Translations.

SPINDLER, L.A., 1929. A Study of the Temperature and Moisture Requirements in the Development of the Eggs of the Dog Trichurid (Trichuris vulpis). The Journal of Parasitology, vol. 16, no. 1, pp. 41-46. http://dx.doi.org/10.2307/3271880.

THOMPSON, R.C.A., LYMBERY, A.J. and SMITH, A., 2010. Parasites, Emerging disease and wildlife conservation. International Journal for Parasitology, vol. 40, no. 10, pp. 1163-1170. http:// dx.doi.org/10.1016/j.ijpara.2010.04.009. PMid:20452354.
VAZ, Z. and PEREIRA, C., 1934. On a new Oxyurid worm parasite of Mus rattus. Folia Clinica et Biologica, vol. 6, pp. 16-18.

VEJZAGIC, N., KRINGEL, H., BRUUN, J.M., ROEPSTORFF, A., THAMSBORG, S.M., GROSSI, A.B. and KAPEL, C.M.O., 2016. Temperature dependent embryonic development of Trichuris suis eggs in a medicinal raw material. Veterinary Parasitology, vol. 215, pp. 48-57. http://dx.doi.org/10.1016/j.vetpar.2015.10.031. PMid:26790737.

VICENTE, J.J., RODRIGUES, H.O., GOMES, D.C. and PINTO, R.M., 1997. Nematóides do Brasil. Parte V: nematóides de mamíferos. Revista Brasileira de Zoologia, vol. 14, suppl. 1, pp. 1-452. http://dx.doi.org/10.1590/S0101-81751997000500001.

VIEIRA DE SOUZA, M., 2013. Parasitos encontrados em coprólitos do Parque Nacional Serra das Confusões, Piauí, Brasil. Rio de Janeiro: Fundação Oswaldo Cruz, 101 p. Dissertação de Mestrado em Saúde Pública.

VIEIRA DE SOUZA, M., CHAVES, S.A.M., HUGOT, J.P. and IÑIGUEZ, A.M., 2019. New parasite records from Kerodon rupestris (Rodentia, Caviidae) an endemic species to Northeastern Brazil. Oecologia Australis, no. Octobre, pp. 1109. [in press]

VIEIRA DE SOUZA, M., SIANTO, L., CHAME, M., FERREIRA, L.F. and ARAÚJO, A., 2012. Syphacia sp. (Nematoda: Oxyuridae) in coprolites of Kerodon rupestris Wied, 1820 (Rodentia: Caviidae) from 5,300 years BP in northeastern Brazil. Memorias do Instituto Oswaldo Cruz, vol. 107, no. 4, pp. 539-542. http:// dx.doi.org/10.1590/S0074-02762012000400015. PMid:22666866.

WOLF, J. and SHERMAN, P.W., 2007. Rodent Societies: An ecological and evolutionary perspective. Chicago: University of Chicago Press. 610 p.

YAMAGUTI, S., 1963. Systema Helminthum. New York: Interscience Publishers. 